\title{
Konzerviranje zračenjem u spašavanju ratom ugroženih kulturnih dobara - primjer ratne evakuacije i zaštite inventara crkve sv. Ladislava u Pokupskom
}

Katušin-Ražem, Branka; Pedišić, Anđelko

Source / Izvornik: Institucije povijesti umjetnosti : zbornik 4. kongresa hrvatskih povjesničara umjetnosti, 2019, 197 - 204

Conference paper / Rad u zborniku

Publication status / Verzija rada: Published version / Objavljena verzija rada (izdavačev PDF)

https://doi.org/10.31664/z4khpu.27

Permanent link / Trajna poveznica: https://urn.nsk.hr/urn:nbn:hr:254:707707

Rights / Prava: Attribution 4.0 International/Imenovanje 4.0 međunarodna

Download date / Datum preuzimanja: 2023-04-26

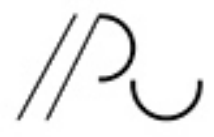

INSITIUTZZ POVIJEST UMJETNOSI
Repository / Repozitorij:

PODEST - Institute of Art History Repository

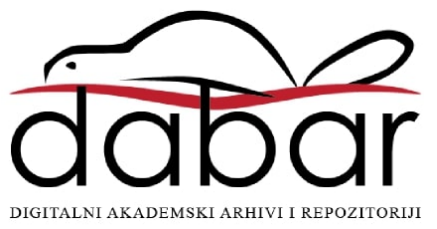




\section{Konzerviranje zračenjem u spašavanju ratom ugroženih kulturnih dobara-primjer ratne evakuacije i zaštite inventara crkve sv. Ladislava u Pokupskom}

Branka

Katušin-Ražem

\section{Anđelko Pedišić}

Branka Katušin-Ražem

Institut Ruđer Bošković, Zagreb

brazem@irb.hr

(D) https://orcid.org/oooo-ooo2-4I59-2I 32

Anđelko Pedišić

Hrvatski restauratorski zavod, Zagreb apedisic@h-r-z.hr

https://orcid.org/oooo-oooi-6884-926o

\section{Uvod}

Rat koji se vodio na tlu Hrvatske i koji je slijedio nakon raspada Jugoslavije ozbiljno je ugrozio sveukupnu hrvatsku baštinu. Već tijekom jeseni I99I. godine tadašnji konzervatorsko-restauratorski zavodi započeli su veliku akciju spašavanja pokretne baštine. Muzejsko-galerijske zbirke, crkveni, knjižnični i arhivski inventari pohranjivani su u predviđene, ali često improvizirane prostore. Mnogi su predmeti premještani i po nekoliko puta, a najčešće se nije moglo izbjeći ostavljanje većih predmeta in situ, što se prije svega odnosilo na crkveni inventar $^{1}$ (sl. I).

Republički je zavod za zaštitu spomenika kulture Ministarstva kulture i prosvjete i994. godine procijenio da je u akcijama konzervatora i restauratora i uz intenzivnu suradnju pripadnika Zbora narodne garde i poslije Hrvatske vojske, crkve i drugih angažiranih grupa i pojedinaca, pohranjeno oko 6ooo sanduka s evakuiranim predmetima u trideset malih „sigurnih skloništa" i u četrnaest velikih službenih depoa, pri čemu su u samo dva ili tri bili osigurani zadovoljavajući mikroklimatski uvjeti i mogućnost kontrole insekata i glodavaca. ${ }^{2}$

Do ideje o osnivanju središnjega ratnog depoa s restauratorskom radionicom usmjerenom na sanaciju ratnih šteta došlo se već tijekom r99ı. godine. Od četrnaest određenih službenih depoa najbolje uvjete za pohranu umjetnina pružala je zgrada dvorca Batthyány u Ludbregu, kako zbog udaljenosti od ratišta, tako i zbog velikoga smještajnog kapaciteta. Grad Ludbreg ustupio je r992. godine dvorac za potrebe ratnog depoa, a zahvaljujući donacijama bavarskih nadbiskupija MünchenFreising i Bamberg te Bavarskog državnog ureda za zaštitu spomenika kulture u dvorcu je ig94. godine otvorena restauratorska radionica. ${ }^{3}$

U katastrofama kao što su ratna zbivanja ne mogu se potpuno provesti ni najsavršeniji planovi spašavanja i zaštite, pa je u ratu nastradao znatan dio spomenika kulturne baštine. Spomenici kulture bili su posebno ugroženi jer su upravo
I ŽELIMIR LASZLO, Zaštita i obnova pokretnih spomenika kulture u ratu, u: Informatica Museologica, 23/I-4 (I992.), 58-6I.

2 Ratne štete nanesene muzejima, galerijama i muzejskim zbirkama u Republici Hrvatskoj. Izvještaj misije ICOM-a (Međunarodnog savjeta za muzeje), veljača I994., ICOM Pariz, u: Informatica museologica, 24/I-4, (I993.), 8-22, II.

3 Restauratorski centar Hrvatskog restauratorskog zavoda u Ludbregu (Ludbreg, brošura u povodu obilježavanja dvadesete obljetnice djelovanja Restauratorskog centra Ludbreg), (ur.) Mario Braun, 2OI4., I2. 


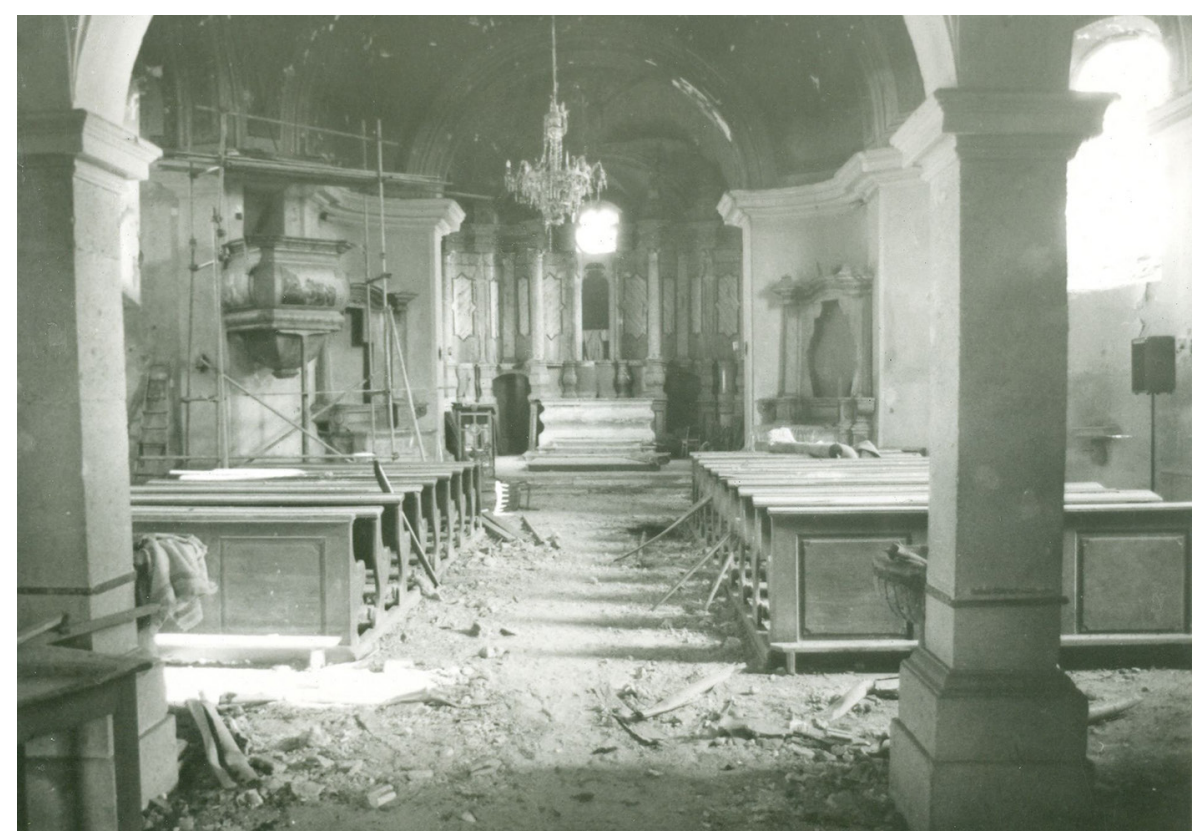

Slika I

Pokupsko, župna crkva sv. Ladislava, unutrašnjost crkve nakon artiljerijskog napada, snimio Ivan Gjurić; inv. br.: $5^{2 \mathrm{I} 4 \mathrm{I}}$

Slika 2

Pokupsko, župna crkva sv.

Ladislava nakon artiljerijskog napada, MK-UZKB-F,

snimio Želimir Laszlo, I99I. god.; inv. br.: 52137

Slika 3

Pokupsko, župna crkva sv. Ladislava nakon artiljerijskog napada, MK-UZKB-F,

snimio Z. Božičević, I99I. god: inv. br:: 50578
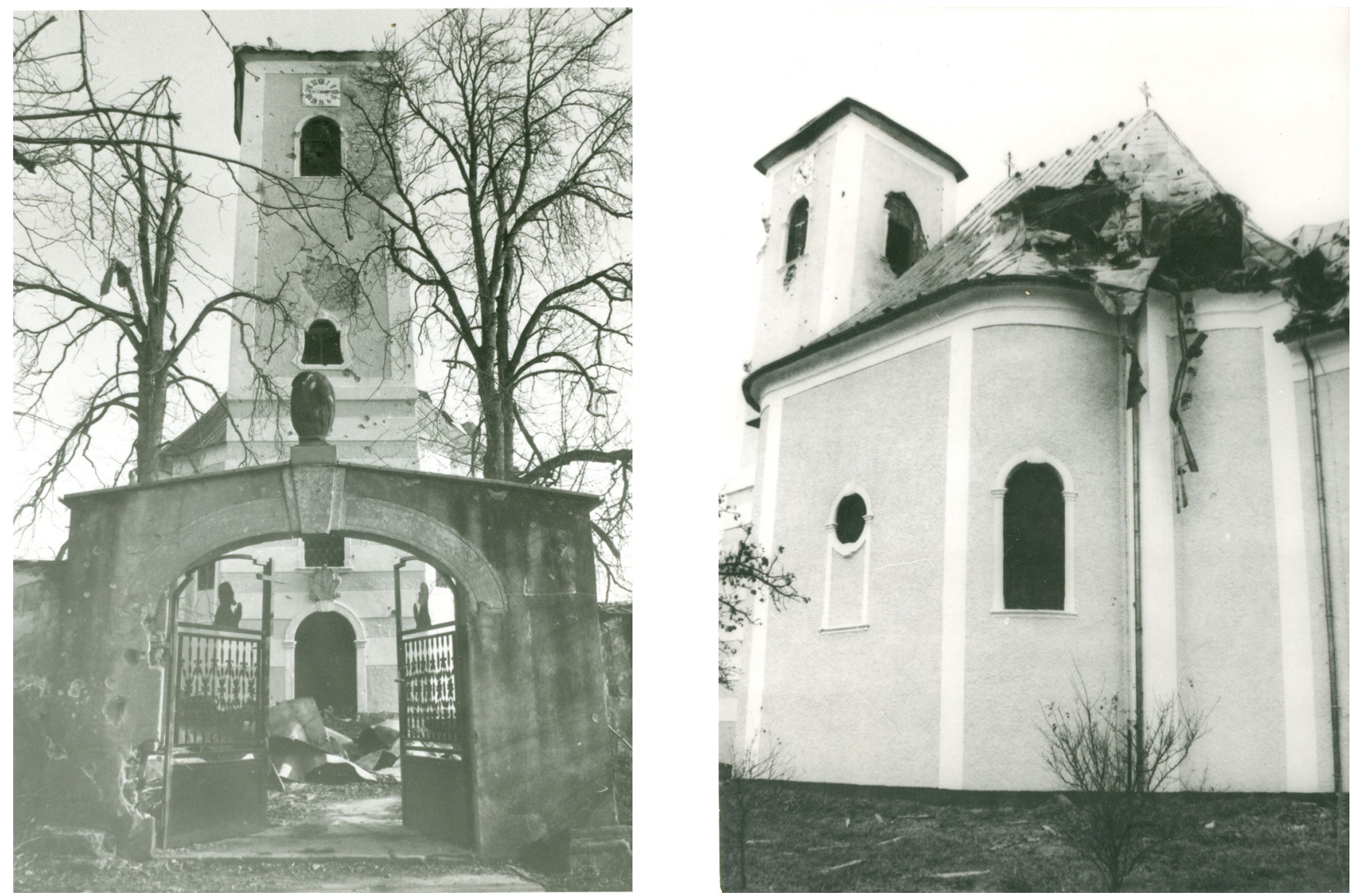
zbog svoje simboličke vrijednosti bili meta namjernoga razaranja (sl. 2, 3). Prema evidenciji Zavoda za zaštitu spomenika kulture, do kraja I99I. godine već je stradalo 507 povijesnih građevina, a prema završnom izvješću Državne komisije za popis i procjenu ratne štete, do kraja rata taj je broj narastao na 2423 , što je iznosilo oko $40 \%$ ukupnoga hrvatskog spomeničkog fonda graditeljske baštine. ${ }^{4} \mathrm{Na}$ popisu nestalih, uništenih i oštećenih predmeta iz crkava, samostana, manastira i župnih dvorova (I62 objekta) nalazi se 3098 predmeta (slika, skulptura, crkvenog posuđa, misnog ruha, crkvenog namještaja i sl.). ${ }^{5}$ Štete u muzejima i galerijama koje je popisao Muzejski dokumentacijski centar broje 3178 uništenih i 2283 oštećena predmeta. ${ }^{6}$

Ratni uvjeti, poremećeno održavanje i čuvanje, seljenje i neprikladni privremeni skladišni prostori uzrokovali su ozbiljno pogoršanje stanja predmeta kulturne baštine. Da bi se smanjio problem biodegradacije širokih razmjera, trebalo je što prije početi organizirano primjenjivati mjere zaštite od kukaca i mikrobioloških štetnika. Pritom je bilo važno izabrati metodu koja će omogućiti tretiranje što većeg broja predmeta u što kraćem roku. Tri glavne metode koje su bile dostupne i koje su se tada mogle primijeniti u Hrvatskoj bile su dezinsekcija metil bromidom, dušikom i gama-zračenjem. Širu uporabu metil bromida ograničava velika otrovnost plina i njegova štetnost po okoliš. Glavni nedostatak za širu primjenu dušika u ratnim godinama bila je sporost postupka i činjenica da se ne uništavaju plijesni i gljivice. U Restauratorskom centru u Ludbregu (dalje: RCL) Hrvatskoga restauratorskog zavoda (dalje: HRZ) dezinsekcija dušikom ušla je u primjenu tek 1995. godine. ${ }^{7}$ Dok kod navedenih metoda s plinovima postupci traju i po nekoliko tjedana, kod primjene treće metode, dezinfestacije zračenjem, trajanje postupka mjeri se u satima. Metoda efikasno uništava i suzbija insekte i mikrobiološke štetnike, a istodobno omogućava obradu veće količine ugroženih predmeta. Metoda dezinfestacija gama-zračenjem bila je dostupna u Institutu Ruđer Bošković (dalje: IRB) u Zagrebu, gdje se za obradu materijala rabila još od ig84. godine. ${ }^{8} \mathrm{Za}$ nužno i hitno spašavanje ratom ugroženih kulturnih dobara preporučili su je i bavarski stručnjaci, koji su s njom već imali pozitivna iskustva.

\section{Načela i postupak konzerviranja zračenjem}

Radijacijski postupak zaštite predmeta kulturne baštine široko je primjenjiva interventna, fizikalna, nekontaktna metoda. Sastoji se u kontroliranom izlaganju predmeta napadnutih insektima ili mikrobiološkim štetnicima ionizirajućem gama-zračenju, čiji biocidni učinak zaustavlja biodegradaciju. Gama-zračenje radioaktivnog izotopa ${ }^{60} \mathrm{Co}$ prodire kroz sve materijale i uništava biološke organizme koji se u njima nalaze. Univerzalni biocidni učinak zračenja zasniva se na svojstvu zračenja da proizvodi kemijska oštećenja molekule DNK, koja je sastavna komponenta svih živih organizama. Time se
4 RANKA SARAČEVIĆ-wÜRTH, Kulturna baština-spašavanje, u:Zbornik referata sa Stručnog okruglog stola o sklanjanju stanouništva i materijalnih dobara, 2005., 37-4I, 39

5 RANKA SARAČEVIĆ-wÜRTH (bilj. 4), 39.

6 Ratne štete na muzejima i muzejskoj građi u Hrvatskoj, Muzejski dokumentacijski centar, Zagreb, http://ratne-stete.mdc.hr/hr/ratne-stete/ (posjećeno I. studenoga 2016).

7 VELIMIR IVEZIĆ, Restauratorski centar Ludbreg, projekt hrvatskih i bavarskih stručnjaka, u: Radovi Hrvatskog društva folklorista, 7 (I998.), I9I-206, I92.

8 DUŠAN RAŽEM, Radijacijska tehnologija, u: Tehnička enciklopedija, sv. II, Zagreb, Jugoslavenski leksikografski zavod, I988., $386-398$ 
onemogućava njihovo razmnožavanje, odnosno opstanak njihovih kolonija u ozračenim predmetima.

Kod postupka ozračivanja najvažniji je parametar količina apsorbirane energije zračenja, koji se zove doza zračenja. Potrebna se doza određuje uzimajući u obzir tri čimbenika: razinu početne količine štetnika, radioosjetljivost štetnih organizama i željeni faktor njihove redukcije. Radioosjetljivost se definira kao $\mathrm{D}_{10}$, doza s kojom se razina nametnika reducira za faktor Io. Zahvaljujući dugogodišnjoj industrijskoj primjeni radijacijske metode i istraživanjima na području radiobiologije, poznate su radioosjetljivosti (vrijednosti $\mathrm{D}_{10}$ ) svih vrsta gospodarski relevantnih insekata i mikrobioloških nametnika, a na temelju bogatih iskustava o tipičnim početnim nivoima zagađenja (kontaminacijama) došlo se do doza zračenja preporučljivih u praksi radijacijskog postupka. Dok se za radijacijsku sterilizaciju (uništenje bakterija) obično primjenjuje doza od 25 kGy, za suzbijanje gljivica i plijesni dostaje 2-ıo kGy. Doza koja učinkovito prekida razmnožavanje i evoluciju svih faza razvoja kukaca iznosi o,5-2 kGy. ${ }^{9}$

Prilikom ozračivanja predmeta sastavljenih od osjetljivih prirodnih polimera, npr. papira, tekstila i kože, dozu treba prilagoditi tako da najmanja doza učinkovita protiv čimbenika biorazgradnje istovremeno bude manja od doze koja bi izazvala degradaciju materijala. Kod pravilno obavljena ozračivanja nema nikakvih ili gotovo nikakvih štetnih posljedica za materijale od kojih su izrađeni. ${ }^{10}$ Također, nakon prestanka ozračivanja, prestaje bilo kakvo djelovanje zračenja u predmetu, a on ozračivanjem ne postaje i sam radioaktivan, pa iz njega nema sekundarne radijacije. Ozračeni predmet potpuno je neškodljiv za korisnike i okolinu.

Radijacijski postupak u zaštiti predmeta kulturne baštine razvijao se usporedo s komercijalnim postupcima sterilizacije medicinskih i farmaceutskih materijala te dekontaminacije hrane i kozmetike. ${ }^{11}$ Naročiti doprinos dale su pritom komercijalne tvrtke za ozračivanje koje su tijekom pedeset godina obrađivale isključivo predmete kulturne baštine: Laboratoire ARC-Nucleart, CEA, Grenoble, Francuska i Uređaj za konzerviranje zračenjem, Muzej Središnje Češke, Roztoky, Češka. Hrvatsko iskustvo u uporabi zračenja za zaštitu kulturne baštine omogućili su izgradnja i uporaba vlastitog uređaja za ozračivanje gama-zrakama ${ }^{60} \mathrm{Co} u$ Laboratoriju za radijacijsku kemiju i dozimetriju (dalje: LRKD) u IRB-u. Osim za znanstvena istraživanja, uređaj se od I983. godine upotrebljava za komercijalna ozračivanja medicinskih potrepština, farmaceutika, kozmetičkih materijala i namirnica u svrhu njihove sterilizacije, dekontaminacije i dezinfestacije. ${ }^{12} \mathrm{U}$ više od 25 godina uređaj se rabi i za očuvanje i zaštitu predmeta kulturne baštine. U suradnji s HRZ-om i drugim institutima, muzejima, galerijama, fakultetima, knjižnicama i srodnim ustanovama, ozračivanjem je tretirano više od 8000 drvenih skulptura, dijelova oltara, pokućstva, muzičkih instrumenata, alata te drugih drvenih, papirnih, kožnih i tekstilnih predmeta. ${ }^{13} \mathrm{Na}$ području zaštite kulturne baštine nuklearnim metodama IRB i HRZ su tijekom posljednjih dvadesetak godina uključeni u
9 MARIANNA ADAMO, GIUSEPPE MAGAUDDA, ANTONINO TATA, Radiation Technology for Cultural Heritage Restoration, u: Restaurator, 25 (2004.), I59-I70.

IO IRINA PUCIĆ, BRANKA MIHALJEVIĆ, KATJA KAVKLER, Material Response as a Criteria for the Approach to Radiation Treatment of Cultural Heritage Objects, $\mathrm{u}$ : Protection of Cultural Heritage from Natural and Man-made Disasters, International Scientific Conference, Zagreb/Šibenik, 8-ıo May 20I4, National and University Library in Zagreb, http://chp.nsk. hr/wp-content/uploads/2OI4/I2/Pucić_Mihaljević_ Kavkler_Material\%2oresponse\%2oas\%2oa\%2o criterion $\% 2$ ofor $\% 2$ othe $\% 2$ oapproach $\% 2$ oto $\% 20$ radiation $\% 2$ otreatment $\% 2$ oof $\% 2$ ocultural $\% 2$ oheritage $\% 200$ bjects.pdf (posjećeno I. studenoga 20I6.).

II R. RAMIERE, Protection de l'environnement culturel par les techniques nucleaires, u: Industrial Application of Radioisotopes and Radiation Technology, proceedings of an International Conference on Industrial Application of Radioisotopes and Radiation Technology organized by the International Atomic Energy Agency and held in Grenoble, France, 28 September-2 October I98I, Vienna, International Atomic Energy Agency, I982., 255-270.

I2 DUŠAN RAŽEM, Twenty years of radiation processing in Croatia, $\mathrm{u}$ : Radiation physics and chemistry, $7 \mathrm{I}$ (2004.), 597-6o2.

I3 BRANKA KATUŠIN-RAŽEM, DUŠAN RAŽEM, MARIO BRAUN, Irradiation treatment for the protection and conservation of cultural heritage artefacts in Croatia, u: Radiation Physics and Chemistry, 78 (2009.), 729-73I; IRB/HRZ Seminar Radijacijske metode $u$ zaštiti kulturne baštine, Zagreb, 4.-6. Io. 20II., http:// www.h-r-z.hr/index.php/djelatnosti/struni-skupovi/3I8-radijacijske-metode-u-zatiti-kulturne-batine (posjećeno I. studenoga 20I6.); IRB/HRZ/Međunarodni centar za podvodnu arheologiju Ciklus predavanja Radijacijske metode u zaštiti kulturne baštine, Zadar, 6.Io.2oII., http://www.h-r-z.hr/en/index.php/ djelatnosti/struni-skupovi/352-irradiation-methods-in-the-protection-of-cultural-heritage (posjećeno 25. studenoga 20I9.); BRANKA KATUŠIN-RAŽEM, MARIO BRAUN, DUŠAN RAŽEM, BRANKA MIHALJEVIĆ, IRINA PUCIĆ, The state of the art in radiation processing for cultural heritage in Croatia, u: Uses of Ionizing Radiation for Tangible Cultural Heritage Conservation, Chapter 27, (20I7.), 207-2I6. IAEA Radiation Technology Series No. 6, International atomic energy agency Vienna, http:/www-pub.iaea.org/ MTCD/Publications/PDF/I6-I782I_PUBI747_web.pdf (posjećeno 25. studenoga 20I9.) 
međunarodne projekte pod pokroviteljstvom Međunarodne agencije za atomsku energiju (IAEA). Takve aktivnosti doprinose promicanju, prepoznavanju i široj upotrebi nuklearnih metoda, kako u Hrvatskoj tako i na međunarodnom planu.

\section{Uređaj za ozračivanje u Institutu Ruđer Bošković}

Laboratorij za radijacijsku kemiju i dozimetriju IRB posjeduje izvor gama-zraka koji je jedini te vrste u Hrvatskoj. Po jačini nadmašuje sve gama-izvore koji se koriste u hrvatskim bolnicama za liječenje zloćudnih tumora zajedno. Uređaj za ozračivanje u LRKD-u panoramskog je tipa: kad se obavlja ozračivanje, izvor zračenja, radioaktivni izotop ${ }^{60} \mathrm{Co}$ nalazi se $u$ središtu prostorije za ozračivanje, a gama-zračenje se od njega širi radijalno po svem prostoru s izloženim predmetima. Kad je potrebno ući u prostoriju za ozračivanje ili kad se uređaj ne koristi, izvor se sklanja u sigurni položaj u olovni spremnik na dnu bunara duboko ispod poda komore. Izvor zračenja ima oblik valjkastog kaveza, čije rešetke tvore šipke ${ }^{60} \mathrm{Co}$. Prostorija za ozračivanje pravokutnog je oblika u kojoj ima mjesta za 4-6 m³ materijala u svakoj šarži (sl. 4). Radi zaštite osoblja koje upravlja izvorom uređaj je izoliran debelim betonskim zidovima i olovnim vratima u skladu s propisima o zaštiti od zračenja (sl. 5). Poznavanje topografije polja zračenja nužno je za osiguravanje točno određene doze zračenja potrebne za obradu pojedinih predmeta. Polje zračenja izmjereno je s pomoću etanol-klorbenzenskog dozimetrijskog sustava, koji je također osmišljen u LRKD-u. ${ }^{14}$

\section{Zračenje u spašavanju ratom ugroženih kulturnih dobara}

U akciji spašavanja, evakuacije i zaštite predvođenoj suradnicima iz HRZ-a, u IRB su već od I99I. godine na zračenje sukcesivno donošeni ugroženi predmeti kulturne baštine. $\mathrm{Na}$ uređaju za ozračivanje u LRKD-u umjetnine su mogle biti tretirane brzo i efikasno neposredno nakon evakuacije, a prije neposredna smještanja u restauratorske radionice ili depoe. Procijenjeno je da je trećina umjetnina izmještenih u sjevernoj Hrvatskoj, uglavnom sakralnih predmeta (što sačinjava oko I500 oltarskih cjelina) ozračivana dezinsekcijskom, a po potrebi i dezinfekcijskom dozom zračenja kao prvi korak u postupku konzerviranja. ${ }^{15}$ Osim zaustavljanja biodegradacije u ozračenom predmetu, radijacijski postupak omogućuje i njegovo sigurno uskladištenje s drugim „čistim” predmetima zahvaljujući eliminaciji rizika da takav predmet posluži kao izvor ponovne infestacije (unakrsne kontaminacije) u skladištu. Najveći broj tretiranih umjetnina sklonjen je u središnji ratni depo $u$ adaptiranom dvorcu Batthyány u Ludbregu u povoljnim mikroklimatskim uvjetima. Iako je tu odmah po otvaranju restauratorske radionice i994. godine započelo konzerviranje-restauriranje spašenih predmeta, mnogi ozračeni i preliminarno stabilizirani predmeti još čekaju na dalju
I4 ISO/ASTM, Practice for use of the ethanol-chlorobenzene dosimetry system, $\mathrm{u}$ : Annual Book of ASTM Standards, sv. I2.02, West Conshohocken, PA, American Society for Testing and Materials, 2006., I029-IO39.

I5 BRANKA KATUŠIN-RAŽEM, ROMANA JAGIĆ, MARIO BRAUN, Radijacijska metoda u spašavanju predmeta kulturne baštine u slučajevima ugroženosti širih razmjera, u: Zbornik radova Devetog simpozija Hruatskog društva za zaštitu od zračenja, (ur.) Željka Knežević, Marija Majer, Ines Krajcar Bronić, Zagreb, Hrvatsko društvo za zaštitu od zračenja, 20I3., 77-83; BRANKA KATUŠIN-RAŽEM, BRANKA MIHALJEVIĆ, MARIO BRAUN, Irradiation Method in the Protection of Heritage Objects Endangered by Massive Biodeterioration, $\mathrm{u}$ : Protection of Cultural Heritage from Natural and Man-made Disasters, International Scientific Conference, Zagreb/Šibenik, 8- Io May 20I4, National and University Library in Zagreb, http://chp. nsk.hr/wp-content/uploads/20I4/I2/Katušin-Ražem Mihaljević_Radiation $\% 2$ ochemistry\%2oand $\% 20$ dosimetry\%2olaboratory.pdf (posjećeno I. studenoga 20I6.).

Slika 4

Uređaj za ozračivanje LRKD/ IRB; prostorija za ozračivanje, fototeka LRKD,

snimila Željka Knežević Medija, 20I5. god.

\section{Slika 5}

Uređaj za ozračivanje LRKD/IRB; komandni stol, fototeka LRKD, snimila Željka Knežević Medija, 2oI6. god.
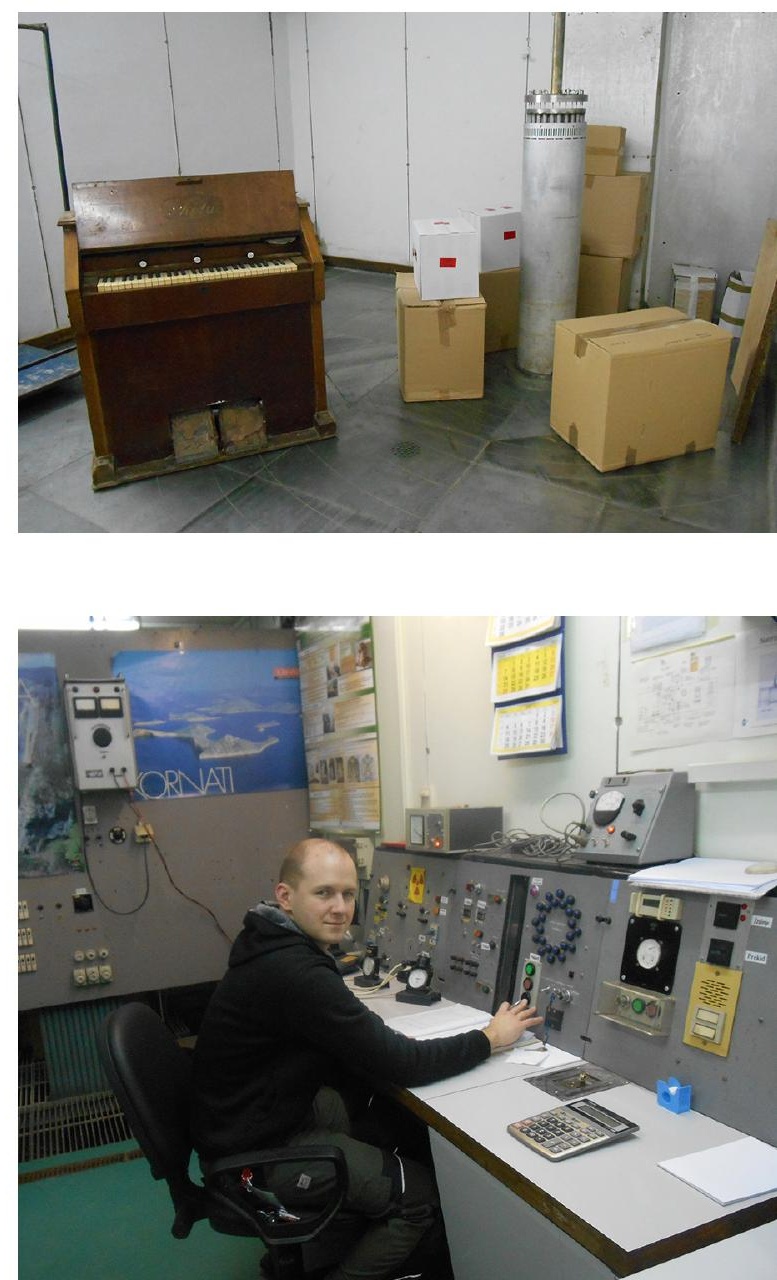
obradu. U povremenoj kontroli stanja više godina uskladištenih ozračenih polikromiranih skulptura nije se pokazala ponovna infestacija, što se može zahvaliti kako povoljnim mikroklimatskim uvjetima, tako i dobro provedenoj dezinfestaciji zračenjem. Iako je velik dio evakuiranih umjetnina restauriran i vraćen vlasnicima, proces obnove i saniranja posljedica ratnih stradanja provodi se još i danas u HRZ-u i raznim radionicama diljem Hrvatske.

\section{Primjer ratne evakuacije i zaštite inventara crkve sv. Ladislava u Pokupskom uz dezinsekciju zračenjem}

Oštećenja inventara iz župne crkve u Pokupskom jedan su od mnogobrojnih primjera ratnih šteta na kulturnoj baštini prouzročenih izravnim borbenim djelovanjem, načinom demontiranja, hitnom evakuacijom i transportom te smještajem $u$ priručna spremišta i skloništa koja nisu ispunjavala konzervatorske standarde. Crkva je teško stradala u ratnim razaranjima tijekom listopada i studenog 199I. godine. ${ }^{16}$ Lukovica tornja bila je pogođena zapaljivom granatom, pri čemu je u tornju nastao požar koji je zahvatio kor. Od vatre i dima uništen je svod crkve s freskama i baroknim štukaturama, a gornji su dijelovi baroknih oltara nagorjeli (sl. 6, 7).
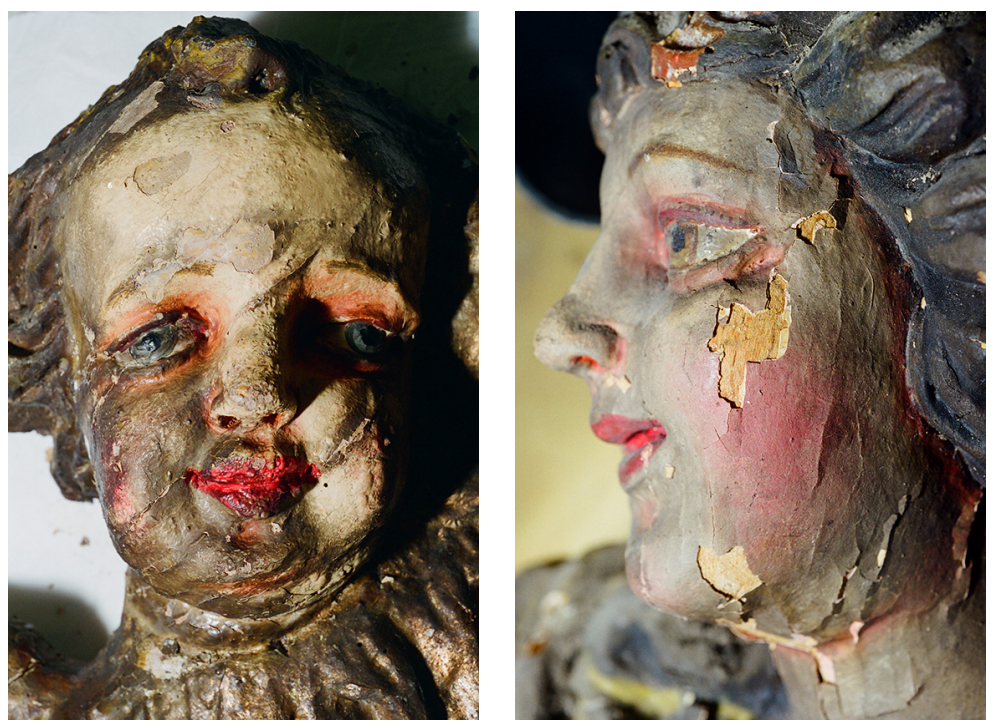

Budući da se Pokupsko nalazilo u ratnoj zoni, iz sigurnosnih razloga nije bilo moguće obaviti privremenu zaštitu građevine od prodora kiše, a velika oštećenja krova, niske temperature i kiše koje su nemilice padale prouzročile su znatna oštećenja na pokretnom inventaru. Ratna evakuacija crkvenog inventara u Pokupskom započela je kao samoorganizirana akcija spašavanja u kojoj je, uz lokalno stanovništvo, sudjelovala Hrvatska vojska, djelatnici lokalnih muzeja, Zavod za zaštitu spomenika
I6 ANĐELKO PEDIŠIĆ, Ratna evakuacija i pregled zaštitnih radova na pokretnom inventaru iz župne crkve sv. Ladislava u Pokupskom, u: Portal, 5 (20I4.), I93-2I0, I93.

Slika 6

Pokupsko, župna crkva sv. Ladislava, glava kerubina s atike glavnog oltara, detalj snimljen prije konzervatorsko-restauratorskih radova, fototeka HRZ-a, snimio Miro Dvorščak, I996. god.; br. neg.: 20399

Slika 7

Pokupsko, župna crkva sv. Ladislava, alegorija ljubavi s atike glavnog oltara, detalj snimljen tijekom obrade oštećenja, fototeka HRZ-a, snimio Miro Dvorščak, I998. god.; br. neg.: 27285 

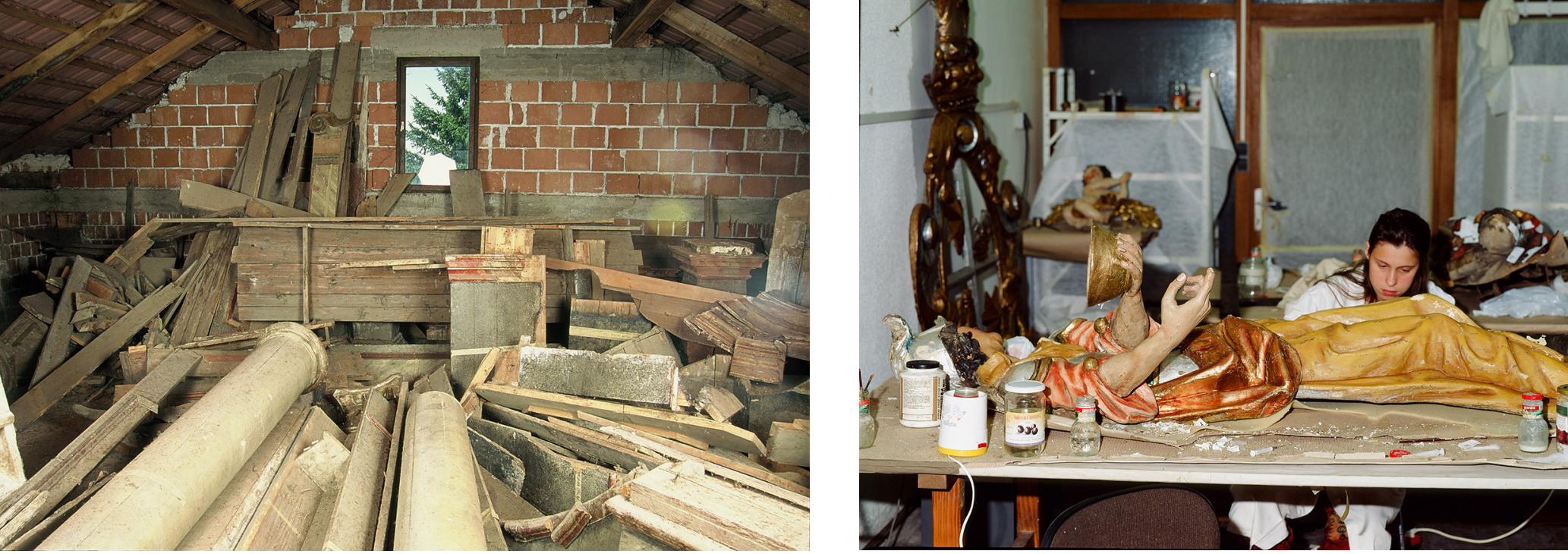

kulture i konzervatorsko-restauratorske službe. Evakuacija inventara obavljena je u tri navrata, a trajala je od studenog 1991. do travnja 1992. godine. ${ }^{17}$ Kao što je to najčešće bio slučaj pri ratnim evakuacijama kulturne baštine, i crkveni inventar sv. Ladislava u Pokupskom bio je sklonjen u podrume i garaže privatnih kuća, a pritom se nije moglo izbjeći ostavljanje većih predmeta in situ. Nedostatni skladišni kapaciteti nisu omogućili pohranu na jednom mjestu, a inventar smještan na više različitih lokacija bio je izložen različitim mikroklimatskim uvjetima. Uz to, mnogi predmeti premještani su i po nekoliko puta (sl. 8).

Konzervatorsko-restauratorski radovi na crkvenom inventaru započeli su i995. godine i traju sve do danas. U studenom I995. godine iz privremenog ratnog skladišta, trezora Zavoda za platni promet u Velikoj Gorici, izvađeno je pet paketa s dijelovima glavnog oltara. Prije unosa oltara u radionice HRZ-a svi dijelovi prvo su bili tretirani gama-zračenjem u IRB-u s desinsekcijskom dozom od I do 2 kGy. ${ }^{18}$ Radovi koji su izvedeni u HRZ-u obuhvatili su sve dijelove bočnih oltara sv. Marije i sv. Josipa te kipove s glavnog oltara sv. Ladislava (sl. 9). Radovi na arhitekturi glavnog oltara povjereni su privatnoj radionici iz Zagreba. Prije početka konzervatorsko-restauratorskih radova dogovoren je normativni koncept, kako bi se na sve dijelove oltara primijenila ista tehnologija, a konačni izgled oltara nakon radova bio ujednačen. Zbog velikog opsega evakuiranog inventara, nedostatnih financijskih sredstava i velikog broja prioriteta nastala ratnom štetom, odlučeno je da se konzervatorsko-restauratorski radovi usmjere na saniranje oštećenja i prezentaciju zadnjeg povijesnog sloja. Konzervatorsko-restauratorski radovi na bočnim oltarima sv. Marije i sv. Josipa dovršeni su 20oo. godine, a na izvorne pozicije u crkvi montirani su 20II. ${ }^{19}$ Konzervatorsko-restauratorski radovi na kipovima i dekorativnoj plastici glavnog oltara sv. Ladislava dovršeni su I999., a na oltarnoj arhitekturi 2016. godine. Zbog velikih dimenzija oltara i velikog broja konstruktivnih elemenata, glavni oltar montiran je prema redoslijedu
Slika 8

Dijelovi glavnog oltara pohranjeni u potkrovlju privatne kuće $u$ Pokupskom, snimila Nikolina Oštarijaš, 2007. godine, fototeka HRZ-a.

\section{Slika 9}

Pokupsko, župna crkva sv. Ladislava, kip sv. Donata sa središnjeg dijela glavnog oltara snimljen tijekom konzervatorsko-restauratorskih radova. Fototeka HRZ-a, snimila Romana Jagić, I996. godine.
I7 ANĐELKO PEDIŠIĆ (bilj. I6), I94. I8 ANĐELKO PEDIŠIĆ (bilj. I6), I98. I9 ANĐELKO PEDIŠIĆ (bilj. I6), 200. 
dovršavanja pojedinih cjelina. Visoko postolje oltara s ophodima postavljeno je u svetište crkve 20og. godine. Radovi na predeli i središnjem dijelu oltara dovršeni su 20II. godine, pa je oltar montiran do visine vijenca. Tada su na središnji dio oltara vraćeni svi kipovi, stupovi i pilastri. Vijenac je montiran 20I2., a atika 20I6. godine (sl. Io).

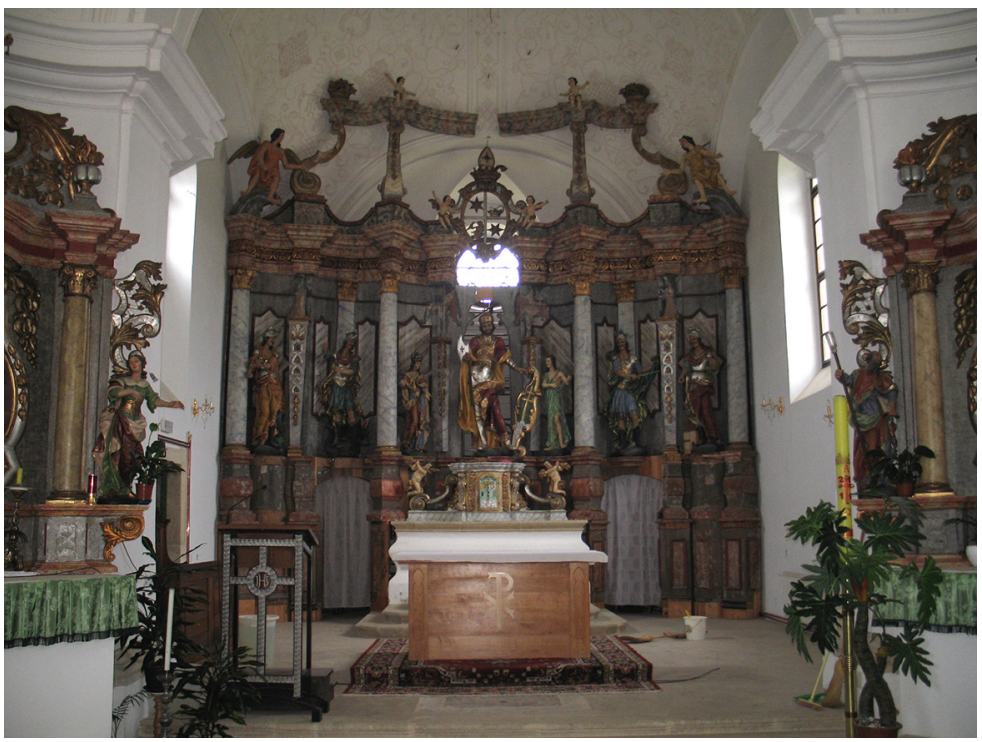

\section{Zaključak}

Spašavanje, evakuacija i zaštita ratom ugrožene kulturne baštine u Hrvatskoj predstavljalo je ozbiljan izazov za mnoge i raznovrsne stručnjake i volontere uključene u zaštitu kulturnih dobara. Kod sprečavanja biološke degradacije širokih razmjera ratom ugroženih umjetnina, kad je u kratkom vremenu bilo potrebno tretirati velik broj predmeta, metoda dezinfestacije zračenjem pokazala se posebno pogodnom i učinkovitom. Takva primjena radijacijske metode na Institutu Ruđer Bošković pri spašavanju predmeta kulturne baštine ugroženih ratom u Hrvatskoj (I99I.-I995.) prepoznata je u međunarodnoj stručnoj javnosti kao posebno uspješan primjer uporabe te metode. ${ }^{20}$ Kao zorni prikaz spašavanja ratom ugroženih kulturnih dobara naveden je primjer ratne evakuacije, zaštite i konzerviranja-restauriranja inventara crkve sv. Ladislava u Pokupskom.

\section{(ㅇ) (1)}

Konzerviranje zračenjem u spašavanju ratom ugroženih kulturnih dobara-primjer ratne evakuacije i zaštite inventara crkve sv. Ladislava u Pokupskom / Branka Katušin-Ražem/Anđelko Pedišić / CC BY / 4.0

DOI: https://doi.org/Io.3I664/z4khpu.27
Slika Io

Pokupsko, župna crkva sv. Ladislava, glavni oltar snimljen in situ 2016 . godine, fototeka Ko Zagreb, snimila Martina Ožanić, 2oı6. godine.
20 News in Conservation, August 2007, https://www. iiconservation.org/node/2332 (posjećeno I. studenoga 20I6.); BRANKA KATUŠIN-RAŽEM, MARIO BRAUN, DUŠAN RAŽEM, Massive preservation of war-damaged cultural heritage objects in Croatia by irradiation, $\mathrm{u}$ : Uses of Ionizing Radiation for Tangible Cultural Heritage Conservation, Chapter 22, (20I7.), I9I-I95. IAEA Radiation Technology Series No. 6, International atomic energy agency Vienna, http:// www-pub.iaea.org/MTCD/Publications/PDF/I6-I782I_ PUBI747_web.pdf (posjećeno 25. studenoga 20I9.) 